IDEAS BEHIND SYMBOLS - LANGUAGES BEHIND SCRIPTS 
Studia uralo-altaica 52

\section{Redigunt}

Katalin Sipőcz

András Róna-Tas

István Zimonyi 


\section{Ideas behind symbols - languages behind scripts}

Proceedings of the 60th Meeting of the Permanent International Altaistic Conference (PIAC)

August 27 - September 1, 2017

Székesfehérvár, Hungary

Edited by Ákos Bertalan Apatóczky

Szeged, 2018 
(C) University of Szeged,

Department of Altaic Studies,

Department of Finno-Ugrian Philology

Printed in 2019

All rights reserved. No part of this book may be reproduced, stored in a retrieval system, or transmitted in any form or by other means, electronic, mechanical, photocopying, recording or otherwise, without the prior permission in writing of the author or the publisher.

Printed by: Innovariant Ltd., H-6750 Algyő, Ipartelep 4.

ISBN: 9789633066638 (printed)

ISBN: 978-963-306-664-5 (pdf)

ISSN: 01334239 


\section{Contents}

Preface

Tatiana Anikeeva

Turkic Manuscripts and Old-Printed Books of the Lazarev Institute of Oriental

Languages: Exploring the History of Oriental Studies in Russia

Chen Hao

Bark: A Study on the Spiritual World of the Early Türks

Oliver Corff

Nations and Rivers: Their Status and Name in the Qingshi Gao Reflections on the

Draft History of Qing as a Source

Balázs Danka

A language behind the script A case study on the Pagan Oyuz-nāmä

Mihály Dobrovits

The Ogur Turks in Chinese records

Hsiang-Tai Kao

The field research on the Manchu inscriptions in Beijing

Bayarma Khabtagaeva

Some notes on kinship terminology in Yeniseian.

Kyoko Maezono

Japanese and Mongolian Usages of the Chinese Writing System

Dieter Maue - Mehmet Ölmez - Étienne de la Vaissière - Alexander Vovin

The Khüis Tolgoi inscription

Rodica Pop

The "five eyes pattern" tavan nüden hee

Maria Magdolna Tatár

Bortz and Membrok, etymology of two Cuman names from the 13th century.....107

Hartmut Walravens

Józef Kowalewski’s Letters to Bernhard Jülg.

Tana $\mathrm{Wu}$

One Language behind Two Different Scripts*

Hülya Yıldız

New Reading Proposal on the Eastern Face, Nineteenth Line of the Bilgä Qayan Inscription 



\title{
The "five eyes pattern" tavan nüden hee
}

\author{
Rodica Pop \\ Bucharest University
}

There are many patterns with symbolic value in the old and current traditions, which are inseparable features from Mongolian society. Originally, the models consisted of basic figures that evolved through various combining possibilities and formed meaningful symbols in everyday life, in nature and space. Thousands of varieties of circular, square or triangular shapes allowed unlimited possibilities to indicate the concrete and abstract phenomena of the universe.

For example, a downward triangular pattern called choinjün or dormon stamp, acquired various symbolic meanings, such as "the sixty feet fandmana hell" (jaran ald jandmana tam) in folktales; "the triangular black hole beyond the eighty one steps" (nayan negen alhmyn tsaadai gurvaljin har nüh) in rituals; "the origin of the black skies" and "the arrow to destroy enemies" in shamanic contexts. ${ }^{1}$ These various patterns along with their symbols can be seen on clothes, jewellery, wallets, bakery articles, cups, pots, furniture, doors, Buddhist temples, buildings, etc. In the nomad world that works through its symbols, they have very different representations, from animals and shamanic accessories, to important and symbolic parts of the Mongolian yurt. For example, snake decorations on the shamans' costumes have the symbolic meaning of invoking spirits. In fact the shaman's whole costume as well as his accessories (drums, sticks, bronze mirrors, etc.) symbolizes the support of spirits, musical instruments, and means of transport or protective armour for the shaman. Two lions on the "wooden chest" (avdar) are to scare evil spirits and misfortunes. Tigers on the Mongolian wrestlers' costumes have the symbolic meaning of protection and gathering strength. The respect given to the "yurt posts" (bagana) because of their good omen, was perpetuated by the concern to decorate them and by the richness in symbols of the ornaments. The carved patterns generally include the "four strong ones": the lion, the tiger, the mystic Garuda bird and the dragon. ${ }^{2}$ Moreover, the posts were always to be cut in birch wood, because the nomads believed that the lightning did not fall on a birch tree (Tangad 1981: 211). The birch wood's white colour, considered auspicious, symbolises the old bloodlines that are the nobility of the steppe in opposition to the commoners, called "black" (harts).

1 Dulam, Mongol belegdel züi. Dürsiin belegdel züi. Dohio zangaany beledgel züi. [Mongolian symbolism. Symbolism of images. Symbolism of gestures], $2007: 166$.

2 Tangad, 'Coutumes mongoles liées au poteau de yourte,' Études mongoles...et sibériennes 21, 1990: 49-50 
The starting point for this paper is a particular symbol found on a 21 by $21 \mathrm{~cm}$ square silk cloth (Figure 1.), dating back to the early twentieth century. Embroidered on each of the four corners of the silk cloth is the chandmani erdene pattern, the "wishing jewel", and in the middle there is a much larger embroidery representing the tavan nüden hee, i.e. the "five eyes pattern". Concerning the origin of this symbol, according to the available Mongolian sources, the "five eyes pattern" belongs to the ancient Mongolian tradition. Its existence is historically proven from the oldest times as meaning nobleness, respectfulness, protection, strength and sacredness.

However, the "five eyes pattern" was not widely used - it was painted or inlaid only on certain objects - unlike other Mongolian symbols such as "the endless knot", "the golden swastika" (altan has) ${ }^{4}$ or the linear pattern of linked swastikas that are very visible. Particular patterns are not used exclusively to decorate different belongings, but are symbols and signs loaded with meaningful values transferred onto the object.

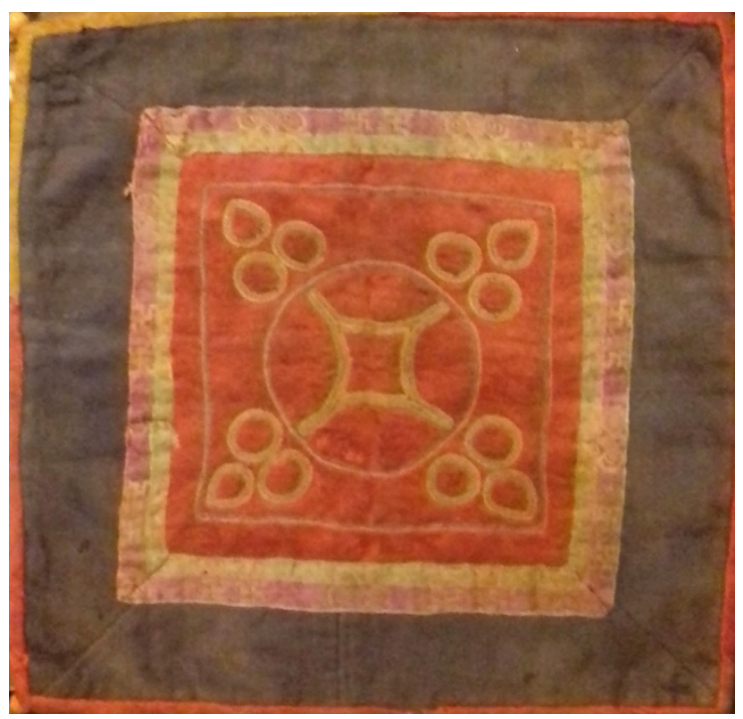

Figure 1.

The question that arises is related to the significance of this very meaningful symbol, which determines its use on a limited scale and only in relation with

3 "The endless knot" (ölzii utas), known also as "the golden endless knot" (altan ölzii utas), symbolizes the infinite love, fortune, good luck and interdependence of all things, associated with happiness and wealth.

4 Swastika (has): (Sanskrit svastika), symbol of good luck, meaning "well-being", "good existence" and "good luck". Has hee is a "linear pattern of linked swastikas." 
certain objects of particular importance for the Mongols. Hence the necessity of making an inventory of the objects on which this symbol is painted, embroidered or carved, in order to decipher it. There is little evidence concerning the existence of "five eyes pattern" symbol. Mongolian sources mention its presence on warriors' armour, on various parts of the horse saddle, on the livestock branding iron instruments, on gold and silver bowls, on the soldiers' weapons, especially on swords and knives.

One of the first manifestations of this symbol in Mongolia refers to warriors who wore armour made up of "five eyes" shaped connected iron rings. Such armour was supposed to protect them and make them vigilant and wary of the whistling arrows coming from the high sky.

\section{The "five eyes pattern" on objects belonging to nomadic households}

Few objects decorated with the "five eyes pattern" are displayed at the National History Museum in Ulaanbaatar. These are items used in everyday life such as a silver bowl, ${ }^{5}$ a door ring, a stirrup handle, an iron seal for branding livestock and a part of the traditional headdress of a bride or married woman.

During the excavations made by the Institute of Archaeology of the Mongolian Academy of Sciences in Töv aimag, Erdene sum at the Sharil cliff, three handles of a drawer in perfect shape, decorated with the "five eyes pattern", were discovered in a tomb dating back to the 13th-14th centuries (Nyamaa and Ganbold, 2007: 84). Archaeological excavations also have revealed three pieces of end tiles (Figure 2.) from the roof of a building from the former capital Harhorin, ${ }^{6}$ dating back to the 13th century, currently exhibited at the National History Museum in Ulaanbaatar. (Nyamaa and Ganbold, 2007: 84).

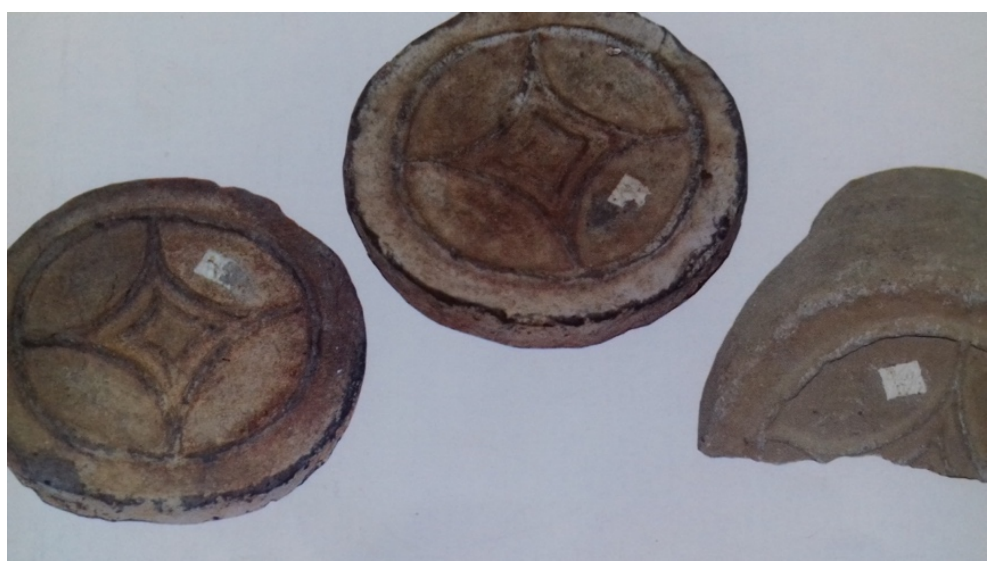

5 In 1959, in a grave of Mongol nobles in the Onon river basin was found a silver bowl with the "five eyes pattern" symbol, carved on the outside bottom. (Nyamaa and Ganbold, 2007: 84).

6 Karakorum. 
Figure 2

The common feature of the objects mentioned above is their essential role in the life of nomadic Mongols. Indeed, the silver bowl, the door ring, the handles of a drawer, as all the belongings forming the economy of a nomad household, are treated with the greatest care, thus decorated with the "five eyes pattern" symbolizing respect, honour, protection and a sacred status. The stirrup is a sacred element of the saddle, being associated with the horse to which the nomad is indissolubly bound. As for the iron for livestock branding (Figure 3), it is indispensable for breeders' housekeeping. Its ornamentation with the "five eyes pattern" symbolizes the concern for livestock's protection and breeders' prosperity.

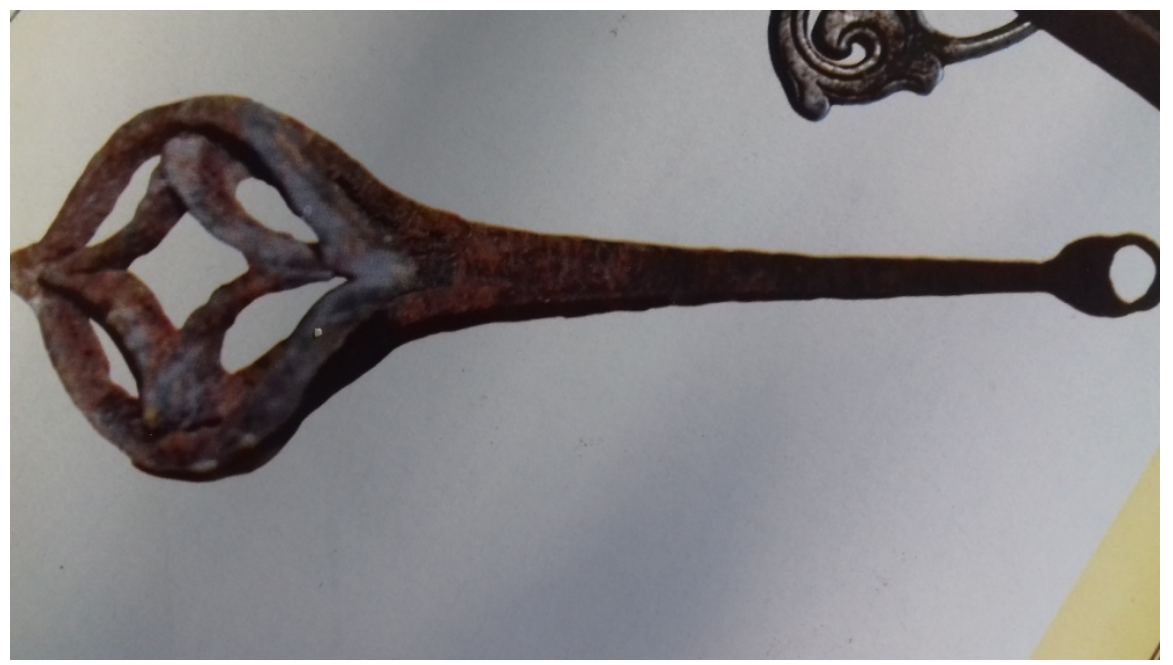

Figure 3

The headdress of a bride decorated with the "five eyes pattern" symbol is linked to the wedding ritual, which is the most important social event, and, therefore, Mongols have appended a meaningful ornament. The "five eyes pattern" decoration on the end tiles of a roof indicates that we have to deal with vestiges of an important building from Harhorin, the house of a noble or a Buddhist temple.

\section{The "five eyes pattern" symbol in the Buddhist tradition}

In the Mongolian Buddhist church, the "five eyes pattern" is the expression of the five elements of astrological calculations: fire, earth, metal, water and wood. This symbol was used generously for decorating Buddhist temples. One example is the decoration of the upper part of the main door of the Gandantegchinlen Buddhist temple in Ulaanbaatar.

Moreover, the small cups for candles, hand-drums, incense-burners, and various objects used in the Buddhist ritual, and sutras are decorated with the "five 
eyes pattern". It glorifies the eternal blue sky and in Buddhism, symbolizes concord, harmony, indestructible force, multiplies the friendship of men, and establishes the Five Celestial Victors ${ }^{7}$ or Jina (yazguurin tavan burhan) and the five colours: blue, red, yellow, white and black.

Another interesting proof supporting the idea that the "five-eye pattern" is used as an ornament only on objects of particular importance is its presence on one side of the silver knife's sheath ${ }^{8}$ belonging to Bogd Haan, used for the dallaga ritual. ${ }^{9}$

\section{The "five eyes pattern" as State symbol}

The Bogd Haan's throne displayed on the first floor of the Bogdo Haan's Palace Museum is covered with sable fur and its back is decorated with golden dragon embroidery. On the dragon, there are $40 \mathrm{~cm}$ yellow silky ribbons hanging on both sides, embroidered with the "five eyes pattern". The presence of this decoration on the throne of a chief of state raises it to state symbol status symbolizing its flourishing and Bogd Haan's infinite peace and happiness (Figure 4).

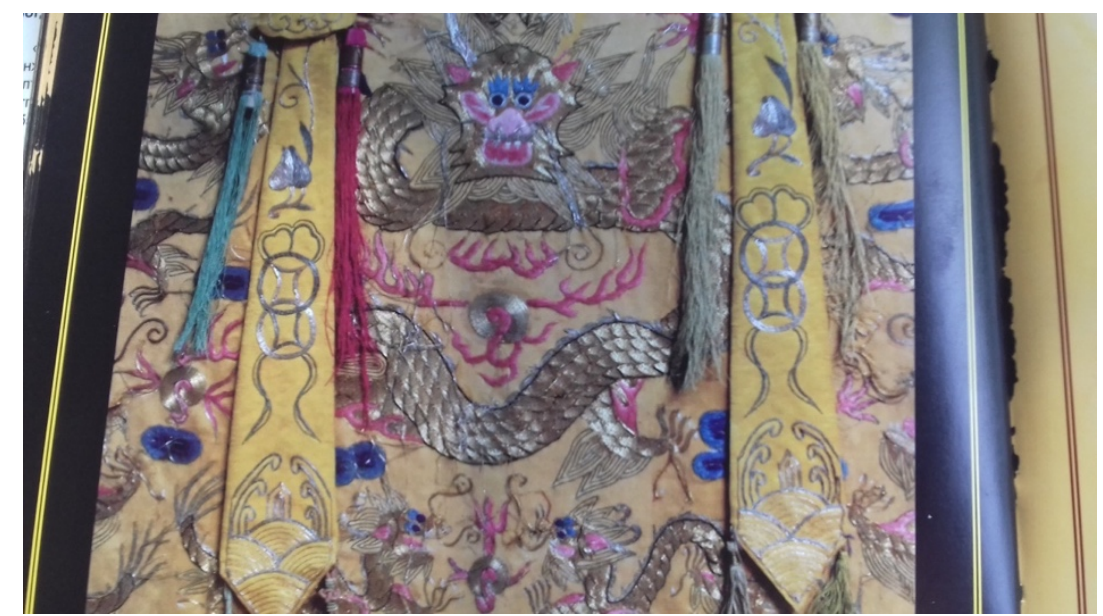

Figure 4

7 The Five Celestial Victors or Jina, consisting of Vairocana, Akshobhya, Ratnasambhava, Amitābha and Amoghasiddhi. (Bawden, 1997: 580-581).

8 The ritual knife was discovered in 1924 when Bogd Haan's belongings were sold and the 64 $\mathrm{cm}$ silver knife was bought by a collector and preserved until nowadays.

9 Dallaga avah, the ritual of appeal of happiness. The lama invited to come to say the prayers, hunts for harmful things in the house and calls for prosperity. "Making circular movements in a clockwise direction" (dallah) is the specific movement of the dallaga ritual to invoke good fortune and prosperity. 
Besides Buddhist monks' gown the Bogd Haan wore state ceremonial clothes. ${ }^{10}$ In the detailed survey made in his volume on the Mongolian clothes ${ }^{11}$ the scholar Nyambuu draws attention to the emblem fixed on Bogd Haan's flap of his ceremonial gown. It has a circular shape and around its central part are embroidered precious ornaments-symbols: the four "wishing jewels", the "khan's bracelet" (haan buguivch), ${ }^{12}$ the "queen's earrings" (hatan süih), ${ }^{13}$ the "five eyes pattern", an "elephant tusk" (zaan soyo), a fish (zagas), ${ }^{14}$ etc. and images of mountains and waters. All of these precious patterns were raised to state symbol rank. The presence of the "five eyes" pattern symbol on the throne as well as on the ceremony clothes of Bogd Haan, shows that the rank of this pattern as state symbol was not interrupted over the centuries.

The old history of the "five eyes" symbol reveals that during the Yuan Dynasty, this pattern symbolized the precious tutelary genius. It was, according to a decree, represented only on the clothes of the golden line of Chinggis Khan and on the weapons of the high rank officers and nobility. Chinggis, his younger brothers, his sons, the noble relatives and aristocrats had clothes decorated with the "five eyes "pattern which became a "state symbol" (tör yos). Indeed, During Qubilai's reign, Mongolian nobles' dress or Züsem, ${ }^{15}$ emerged as a primary style for dignitaries. According to the Yuan Empire sutras "any honoured noble and leading ministers wore" the established Züsem (Nyambuu 2002:17). The rules that have an impact on the Mongolian national dress have changed over time. In his book on the history of the Mongolian clothes Nyambuu (2002: 114-115) classifies the nobles according to the symbols embroidered on their clothes, assigning the "five eyes pattern" a first rank symbol (Figure 5).

The custom was preserved from the 17 th, until the beginning of 20 th century.

10 This clothing as well as the throne are exhibited at Bogdo Haan's Palace Museum.

11 Nyambuu, 2002: Mongol huvtsasnii tüüh. [History of Mongolian Clothes]. Tüüh, ugsaatnii züin shinjilgee [History, Ethnographic Survey], Ulaanbaatar.

12 Haan buguivch, "king's bracelet", is the name of a pattern consisting of two linked rings, each with four smaller rings around its circumference, which is a symbol of honesty, peace and love, and complementary of hatan süih symbol.

13 Hatan-süih, "queen's earings", is the name of a pattern consisting of two linked double parallelograms each with a small double ring at the corners, which is a symbol comparable to a wedding ring. The ear ornament, symbol of love and honesty, is complementary of the haan buguivch symbol.

14 In the Mongolian tradition the elephant symbolizes force and the fish means longevity and posterity.

15 Züsem, coat color (animal), cf. Bawden 1997: 186. 




Figure 5

The first rank taiji ${ }^{16}$ nobility had the "five eyes pattern" embroidered on the flap of their ceremonial gown.

The second rank nobility had the altan ölzii utas "golden endless knot" pattern embroidered on the flap of their ceremonial gown.

The third rank nobility had the golden "swastika" altan has pattern embroidered on the flap of their ceremonial gown.

The fourth rank nobility wore ceremonial clothes embroidered with the Chandmani, "wishing jewel" pattern.

The fifth rank nobility had the möngön lavai "silver conch"17 embroidered on the flap of the ceremonial gown.

"Garment is an object of respect and custom, intimately associated with the person, but also with the Mongols and their history” (Even 2012: 111).

\section{The "five eyes pattern" on 14th century coins ${ }^{18}$}

In the central part of the silver coins of the time of Darmashir Khan who reigned between $1327-1333$ in Tsagaadai ${ }^{19}$ Khanate there is the "five-eyed pattern" symbol printed in relief in the middle of a ritual thunderbolt.

16 Taiji, taij, title of nobility held by the descendants of Chinggis Khan and his brothers on the Borjigin line.

17 The "white conch" is one of the eight auspicious symbols blessed by Shakyamuni Buddha. It symbolizes the spread of the sacred teachings and the awakening from ignorance as well as the virtue and merit that result in peace and happiness.

18 These coins are displayed at the National History Museum in Ulaanbaatar. 


\section{The "five eyes pattern" printed on the Mongolian currency of Bogd Haan}

Centuries later the "five eyes pattern" symbol was printed on the beautiful and rare Mongolian banknotes issued in 1921 during the short theocratic monarchy of Bogd Haan which was followed by the first government installed after the victory of the People's revolution. ${ }^{20}$ The so called Baga Bolzoot ${ }^{21}$ was issued as a shortterm government obligation, from April 20 to October 20, 1921 with the purpose of accumulating funds for the government. ${ }^{22}$ The Mongolian dollar was the currency of Mongolia between 1921 and 1925 when together with other circulating currencies, was replaced by the tögrök.

Treasury notes were issued with the denominations of 10, 20, 50 and 100 dollars. The first wooden printing block of the Baga Bolzoot was made by Luvsangombo known as "Black Hands", a monk from the Vangai province of Hüree, a famous craftsman, ${ }^{23}$ and chief of Hüree's wooden block making activities.

Below are the descriptions of each note of baga bolzoot according to its nominal value, limited to the symbols that have been chosen as an ornament for governmental obligations.

\section{The 10 Dollar Note ${ }^{24}$}

The obverse is edged with one centimetre width blue ornament border. The "lotus flower" (badamlyanhua) is placed in the middle of the top of the border and a swastika pattern is placed on the upper right and left corners. Both sides are decorated with two pairs of five "Queen's earrings". The bottom right and left corners are decorated with the "endless knot". The middle of the bottom border is decorated with the "fish" and the "endless knot" patterns on both sides. In the

19 Tsagaadai, (Ca'adai, Caghadai, Tchagatai), the "Whitish", was Chinggis Khan's second son. (Cf. Histoire secrète des Mongols. Trad. Even et Pop, 1994 [1997]: see the genealogical tree p. 38 and paragraphs 242-245, 258, 260, 269-271, 276, 277, 279, 280.

20 The political and historical situation in Mongolia at the outset of the 20th century was the following: the Russian general Baron Ungern-Sternbeg escaped Bolsheviks and fought Chinese troops who occupied Niislel Hüree, the "capital city" in 1921. After driving away the Chinese Guomins, he freed Bogd Haan who was under house arrest at that time and enthroned him as Haan of Mongolia. In these circumstances Mongolia which declared its independence from China in April 1921 released its first national currency, meant to develop the country.

21 There are no significant publications on where, how and by whom the Baga Bolzoot government obligations were issued except the survey of $Z$. Lonjid who carefully studied the historical documents of the Ministry of Finance preserved at the Mongolian National Archives.

22 At that time Mongolia lacked an efficient financial system and the currency of Russia and China, gold and silver coins issued in England, US, or Mexico, Chinese or Manchu silver ingots called Yumbuu, yaks, camels, horses, other livestock, tea and fur were functioning as media of exchange.

23 He carved Bogd Haan's precious jade stamp when Bogd Haant Mongolia became independent from the Manchus in 1911

24 The size of the paper is $185 \times 116 \mathrm{~mm}$. 
centre of the obverse there is the "five eyes pattern" with a diameter of $32 \mathrm{~mm}$ : four of its eyes are painted yellow, white, blue and red, and the central eye is yellow. The reverse is edged by a similar blue border as the obverse. The top and the corners are decorated with the "endless knot" pattern. Both sides are decorated with two pairs of five patterns known as the "King's bracelet" and the bottom corners are decorated with the "fish" pattern. In the upper centre there is a $3 \times 3$ $\mathrm{cm}$ blue colour stamp and a soyombo ${ }^{25}$ symbol. Under the Mongolian script there is a picture of a white sheep (Figure 6).

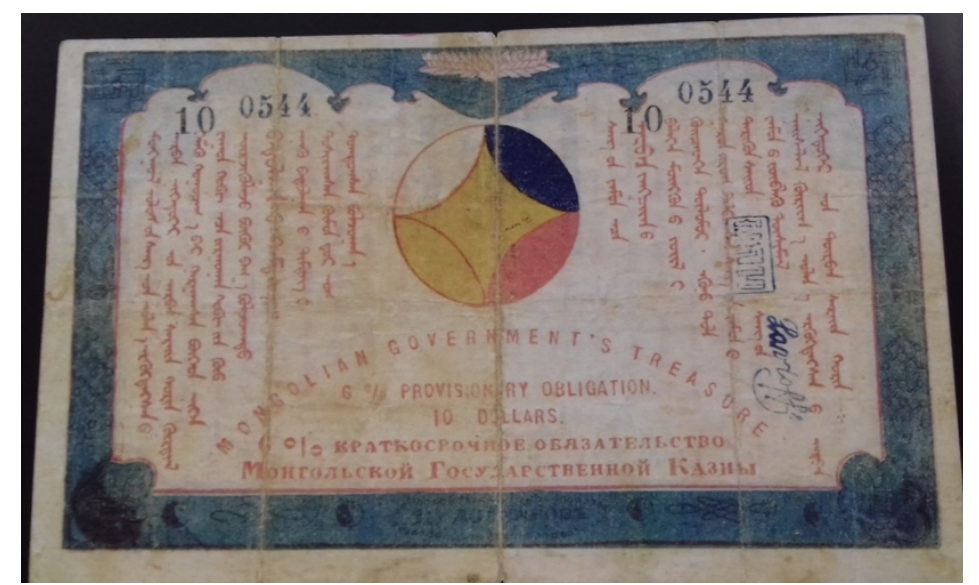

Figure 6

\section{The 25 Dollar Note}

Both sides of the note are edged with a one-centimetre width red ornament border; ornaments and patterns are blue and red in colour. Except for their colour, the symbols printed on the 25 dollar note's face and reverse sides are identical to the 10-dollar note. A red spotted cow is seen on the reverse side under the semicircle in blue background colour (Figure 7).

25 Undoubtedly, Soyombo is the most popular symbol in Mongolia. The Soyombo symbol became a national symbol of Mongolia, and has appeared on the national flag since 1921 and on the Emblem of Mongolia since 1960 as well as on money, stamps etc. Various meanings are proposed for its components; some directly related to the Mongolian people, others oriented more towards Buddhism. Soyombo also inspired a Mongolian script also known as "Soyombo alphabet" developed by the monk and scholar Zanabazar in 1686. 


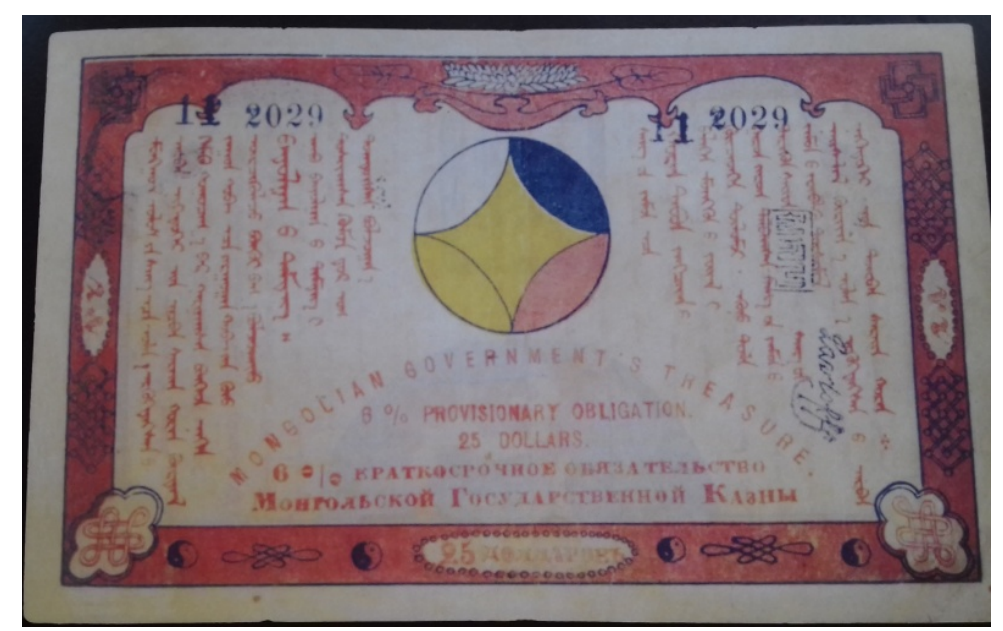

Figure 7

\section{The 50 Dollar Note 26}

The border on the face side is greenish yellow, and the symbols and ornaments printed with red on both sides of the note, are identical to the 10 and 25 dollars notes. The border's colour on the reverse side is dark blue and there is a picture of a white horse facing left, with its mane, tail, and feet in red (Figure 8).



Figure 8

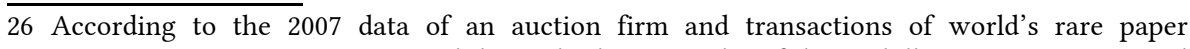
currencies in Europe it was stated that only three samples of the 50 dollar notes are preserved today and are among the world's rarest notes. 


\section{The 100 Dollar Note}

The general characteristics of this note with the highest nominal value are similar to those of the 10, 25 and 50 dollar notes. One difference is that the outer border of the "five eye pattern" symbol on the face side is printed with a double line. The yellow-brown camel facing right is pictured in a semicircle with a light yellow base on the reverse side of the note (Figure 9).

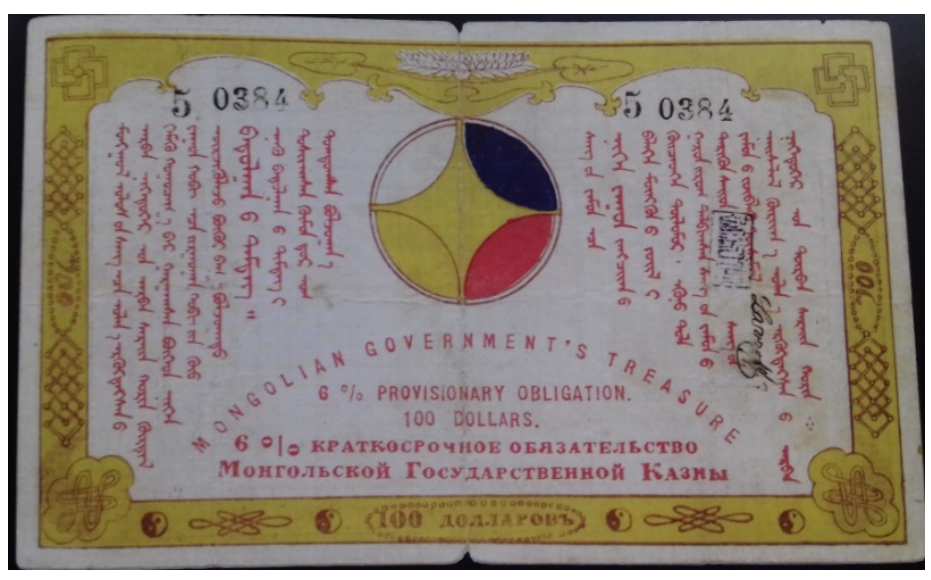

Figure 9

The "five-eye" symbol placed in the centre of the baga bolzoot notes has a relatively large size. Writing about the "five eyes pattern" present on the face of all notes of the baga bolzoot Bogd Haan's currency, L. M. Iolson remarked that this symbol was a "National Emblem of Mongolia" at that time (Nyamaa and BatErdene 2010: 111). Although not an emblem, it has been, since ancient times, a Mongolian symbol of respectfulness and honour.

\section{The "five eyes pattern" printed on the Danzan ${ }^{27}$ dollars in $1921 .^{28}$}

With the victory of the People's revolution, the new government was established in July 1921. The baga bolzoot notes issued by the government of Bogd Haan were withdrawn from circulation for several reasons including the perception that it

27 Soli Danzan (1885-1924) of Sainjin clan was a nationalist and was considered to be a special and odd person. According to his view, "it is right to get a support from Soviet Russia, but we should not develop the country according to the Soviet model" (cf. Nyamaa, B. and BatErdene, D. 2010: 60, 120). This belief led him to his tragic ending. Thus, by direct orders of Elbegdorj Richino, the Bolshevik Party's Representative of the Soviet Russia who came to Mongolia as government advisor, Soli Danzan was unexpectedly arrested on the night of August 26, 1924 and executed few days later.

28 Today, this paper money known as Danzan's Dollar is included with the Baga bolzoot in the Standard Catalogue of World Paper Money and considered one of the rarest paper money in the world. 
was unsuitable for the revolutionary government to use the currency of the former government. Further, a new set of banknotes were printed by the end of 1921, in denominations of 50 cents, 1, 3, 5, 10 and 25 dollars. An Agreement on Printing a National Currency of Mongolia was established and signed by Soli Danzan, the Chairman of the People's Party of Mongolia and Minister of Finance, and Alsky, the Deputy to the Commissioner of the People's Finance of the Soviet Russia on the 24th of November 1921. It was agreed to print a new national currency with six values: 50 cents, $1,3,5,10$, and 25 dollars. ${ }^{29}$ The design was drawn by the famous Mongolian painter Balduu Sharav (also named Marzan ${ }^{30}$ Sharav). The notes are decorated with bright colours and traditional Mongolian patterns. A common symbol on all notes is the "five eye pattern" symbol in different sizes and colours. On the one, five, ten and twenty-five dollar banknotes, the "five eyes pattern" is drawn in combination with the swastika, a double meaning sign considered to be a state symbol ${ }^{31}$ (Figure 10).

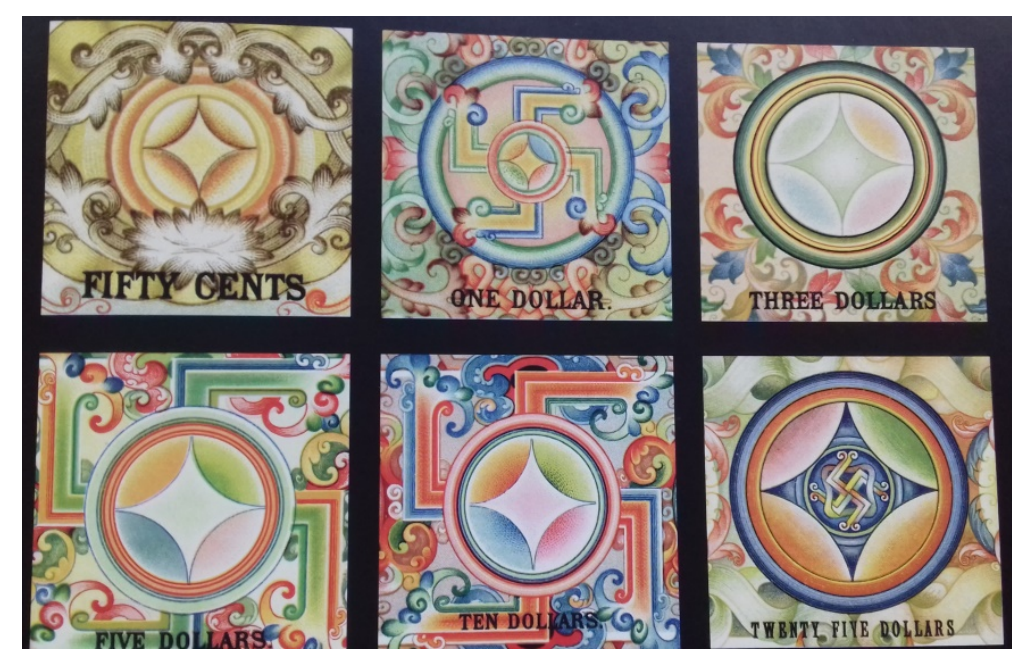

Figure 10

The use of the "five-eye" pattern and its position as a central symbol on both series of banknotes printed in Mongolia at the beginning of the 20th century represents the return of this ancient symbol "in force" six centuries after it had been used embossed on the 14th century silver coins.

Analyzing its graphic representation within the system of values of Mongolian philosophy, we come across the following meanings:

29 The money was printed, according to the agreement with the second Factory of Printing State Securities, in Moscow based on a loan of one million roubles.

30 Marzan, "comic, funny," (Tseveel 1966: 332).

31 Nyamaa, B. and Bat-Erdene, D., 2010: 123. 
- its round shape represents world existence, creation, cosmos, and symbolizes the nomads' camp; it means as well, the law and the rule. ${ }^{32}$

- number "five" tav is a figure with good omen. Mongols have in their culture "the five categories of treatment in traditional medicine" (tavan zasal); "the five elements" (tavan mahbod) - wood, fire, earth, iron, water - ; "the five colours" (tavan öngö) - blue, red, yellow, white, black -, "the five elixirs" (tavan Rashaan) - medicinal decoction of juniper, wormwood, joint pine, labrador tea and pine needles; "the five delights" (tavan tansag) beauty, euphoria, fragrance, savouriness, softness -; "the five Sensuous Offerings" (tavan tahil) - mirror, music, perfume, tasty food, soft materials - ; "the five major sciences" (tavan uhaan) - i.e. the five major branches of learning - in Buddhism, and "the five sorts of livestock" (tavan hoshuu mal) - horse, camel, ox, sheep, goat. This number symbolizes strength, force, power and capacity. ${ }^{33}$

With regard to the colours with which this symbol is represented on the Bogd Haan's Mongolian banknotes issued in 1921,

- white colour symbolizes noble origin: "the good nature" (tsagaan sanaatai), "the shaman's costume" (tsagaan huvtsas), "the white residence, the yurt" (tsagaan örgöö), "the first month of the lunar year" (tsagaan sar) ${ }^{34}$

- blue colour symbolizes spirituality under the protection of "the eternal blue sky" höh mönh tenger and politics through "the establishment of the blue Mongolian State” höh Mongol ulsyg baiguulalt. ${ }^{35}$

- yellow colour symbolizes earth, astrology and astrologists, as well as their sage writings. ${ }^{36}$

- red colour symbolizes heroes; it means straight, absolutely, right. ${ }^{37}$

The revival of the "five eyes" pattern is due to the fact that in the collective memory this model has continued to symbolize Mongolian customs, rule, and historical tradition. This pattern symbolises the first hero originated from the ring of the armour and defence from dangers, glorifies the eternal blue sky and, in Buddhism, symbolizes concord, harmony, unbreakable strength, and spreads human friendship. The "five eyes" became in time a widespread symbol; however it

32 Dulam 2007: Mongol belegdel züi. Dürsiin belegdel züi.[Mongolian symbolism. Symbolism of images] 2007: 82.

33 Dulam, Mongol belegdel. Tooni belegdel züi. [Mongolian symbolism. Symbolism of numbers], 2007: 93.

34 Dulam, Mongol belegdel züi. Öngiin belegdel züi. [Mongolian symbolism. Symbolism of colours] 2007: $16-20$.

35 Ibid. : 23-26.

36 Ibid. : $32-33$.

37 Ibid. : 41. 
is limited to a range of objects that are very important for the Mongols, and therefore recognized as having a complex and powerful meaning. This development shows the importance of these patterns in the frame of Mongolian popular knowledge and symbolic representations, offering us a rare insight into the inner workings of Mongolian culture and ancient Mongolian heritage. Nowadays, this particular pattern can be seen as page-decoration on books published after 2000, as well as a symbol of strength used by some modern institutions. It is used, for example as the logo for a Mongolian bank (Figure 11).

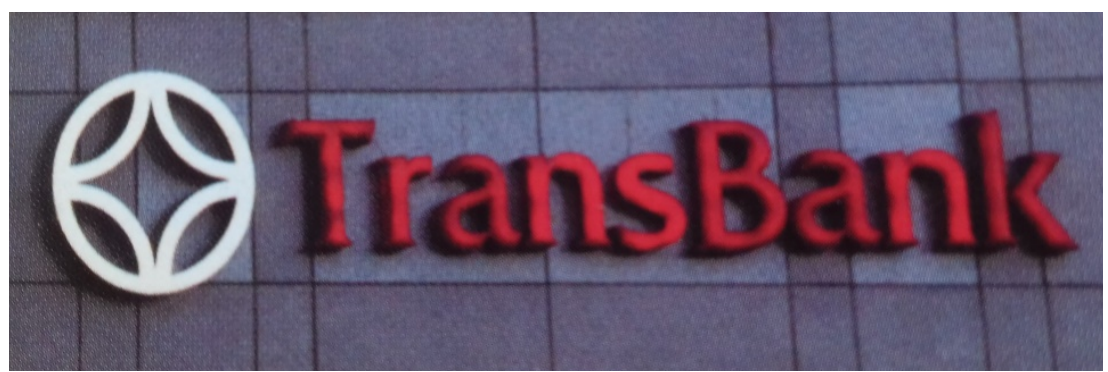

Figure 11

These symbols of high economic, cultural, and scientific achievements of the Mongols, which were left in oblivion under the centuries of long oppression of the Qing Dynasty, ${ }^{38}$ were rediscovered and were used in new shapes and strengthened meaning with independence in the 20th century.

\section{References}

Bawden Charles, 1997: Mongol-English Dictionary, London and New-York, Kegan Paul International.

Delaby, Laurence, 1976, 'Chamanes toungouses', Études mongoles...et sibériennes 7.

Dulam, S., 2007. Mongol belegdel züi. Tooni belegdel züi. [Mongolian symbolism. Symbolism of numbers] Tergüün devter. VIII bot'. Mongol soyoliin chuulgan, Ulaanbaatar.

38 The Qing dynasty, established by the Manchu in 1636, was the last imperial state in China (Yuan Shikai's attempt to establish himself as the "Great Emperor of the Chinese Empire" at the end of 1915 was an utter failure). The Manchu emperors ruled China proper - the territory of the Ming dynasty - for nearly three centuries (1644-1912) and extended their suzerainty over Mongolian, Tibetan and Züünghar (Oirat) territories. The Qing multi-cultural empire was then claimed as its own by the modern Chinese state. 
Dulam, S., 2007. Mongol belegdel züi. Öngiin belegdel züi. Züg chigiin belegdel züi. Mongolian symbolism. Symbolism of colors. Symbolism of direction] Ded devter. IX bot', Mongol soyoliin chuulgan, Ulaanbaatar.

Dulam, S., 2007. Mongol belegdel züi. Dürsiin belegdel züi. Dohio zangaany beledgel $z \ddot{u} i$. [Mongolian symbolism. Symbolism of images] 3-r devter. X bot'. Mongol sojolin chuulgan, Ulaanbaatar.

Even, M.-D., 2012, Les Mongols au tournant du siècle. Populations, sociétés, pratiques vestimentaires, in Anne Sigaud, La Mongolie entre deux ères, catalogue de l'exposition «La Mongolie entre deux ères, 1912-1913» (Musée Albert-Kahn, 29 novembre 2011-16 septembre 2012), Musée Albert-Kahn, Boulogne, 103-120 (trad. in English 121-128).

Nyamaa, B. and Ganbold, G., 2007: Mongolin hoyor töriin möngön temdegt 1921. Currencies of Two Mongolian Governments 1921, Ulaanbaatar.

Nyamaa, B. and Bat-Erdene, D., 2010: Mongol ulsiin güilgeenii möngön temdegt (1221-2010), Circulating Currencies of Mongolia (1221-2010), Ulaanbaatar.

Nyambuu, H., 2002: Mongol huvtsasni tüüh. [History of Mongolian Clothes]. Tü̈̈h, ugsaatnii züin shinjilgee [History. Ethnographic Survey], Ulaanbaatar.

Histoire secrète des Mongols, Chronique mongole du XIIIe siècle traduit du mongol, présenté et annoté par Marie-Dominique Even et Rodica Pop, 1994 [1997]. Gallimard, Connaissance de l'Orient, Paris.

Tangad, D., 1981. Töv Halhad yavuulsan ugsaatnii züin ekspediciin tailan [Ethnographic mission report in Central Halh] Institute of History.

Tangad, D., 1990, 'Coutumes mongoles liées au poteau de yourte', Études mongoles...et sibériennes 21, 37-57.

Tseveel, Ya., 1966. Mongol helnii tovch tailbar tol' [Concise Dictionary of Mongolian Language], Ulsin hevleliin hereg erhleh horoo, Ulaanbaatar. 